Article

\title{
Living Standards in One-Person Households of the Elderly Population
}

\section{Marlena Piekut 10}

Warsaw University of Technology, College of Economics and Social Sciences, 17 Łukasiewicza St., 09-400 Plock, Plac Politechniki 1, 00-661 Warsaw, Poland; Marlena.Piekut@pw.edu.pl

Received: 2 December 2019; Accepted: 24 January 2020; Published: 30 January 2020

check for updates

\begin{abstract}
The number of one-person households of the elderly continues to rise in developed countries. The study assesses the standard of living in this type of households. The aim of this study is to explore the standard of living of single older adults (60+) in Poland by focusing on the relationship between demographic and socio-economic factors as well as their objective financial situation and subjective satisfaction on their financial and consumption standards. To evaluate the standard of living in one-person households run by people aged 60 and over, the aggregate (composite) indicator was designed, based on the Economic Living Standard Index method. The key issues relating to multifaceted aspects of sustainable development are both the level and the quality of life. It can be concluded that the elderly people running one-person households constitute a group that is heterogeneous due to their different socio-economic and demographic characteristics, which in turn affect their various living standards. The highest standard of living can be noticed in the households run by white-collar workers, self-employed persons and well educated persons. The lowest standard of living can be observed in the households run by groups of people including farmers, people having income from social sources (without pensions), living on supplementary welfare allowance and persons with lower education level (secondary, primary or less). Remedial measures should be taken for these social groups. The key factors determining the standard of living in one-person households of the elderly are socioeconomic status and education level.
\end{abstract}

Keywords: single-person households; solos; consumption; elderly people; quality of life; living conditions

\section{Introduction}

The family forming a household undergoes significant transformation in a specific development process, including changes in the variety of household features such as its composition, economic opportunities, financial resources and needs. One of the phases in the household life cycle is related to running a household by a lonely elderly person. Decades ago, at a time when a household was formed by several generations, one-person households run by the elderly were rare. At present, in times of changes in the family model and the impact of other demographic and socio-economic factors, this type of household is becoming more and more popular.

The proportion of older people in the total population is estimated to increase significantly in the forthcoming decades since the larger proportion of the post-war baby boom generation is going to reach the retirement age. The percentage of one-person households amongst the elderly will probably also increase as a result of several factors, among them: a longer life expectancy for women than men, an increase in the number of divorces, as well as an increase in the number of people who consciously choose to live alone.

On the other hand, research shows that the standard of living in many households run by the elderly remains very low [1,2], in particular in one-person households. However, it can be expected 
that the standard of living of elderly people running one-person households is diversified, similarly to the standard of living of other groups $[3,4]$. The following factors were recognized as important determinants of the households' diversity and their consumption situation: education level [5], the source of income [6], the place of residence, marital status [7], gender [8]. Therefore, it became interesting to consider the standard of living in one-person households of people aged $60+$ depending on socio-economic and demographic characteristics.

There were several reasons for undertaking the study:

1. Significant and increasing share of one-person households in the total number of households;

2. Demographic changes in the society structure, demonstrated in growing the number of older people and the necessity to adapt the socio-economic policy of the state to the needs of these people;

3. The special nature of one-person households run by the elderly (so-called: silver singles) not sufficiently recognized in the scientific literature;

4. Large diversity in financial situation resulting from various characteristics of older people running one-person households;

5. The necessity to adapt the goods and service offer to the needs and capabilities of one-person households of the elderly.

The aim of this study was to explore the standard of life of one-person households of the elderly (single older adults (60+)) living in Poland by focusing on the relationship between their demographic and socio-economic factors and their objective financial and consumption situation and subjective financial and consumption satisfaction. The study reflects the increase in the demographic segment of ageing one-person householders. On the basis of the above-mentioned goal and the literature $[9,10]$ the following research main hypothesis was formulated: the socioeconomic group and level of education are key factors in the standard of living in one-person households of the elderly.

Analyzing household budgets for one-person households has another important advantage. The people running alone households are the only decision maker within their household, therefore their optimal choice of the bundle of goods is the optimal choice of the household. This simplifies the analysis of consumption patterns, since the entire household wealth is at their own disposal and there are no economies of scale in consumption which are potentially arising in households with two and more person [11].

The following definitions were adopted in the study:

- A one-person household is a self-supporting person, regardless of whether he or she lives with other people or alone;

- An elderly person is a person aged 60 and over. There are many discrepancies in determining the age (number of years) above which people can be called the elderly. Some researchers call people aged 55 or over "senior" [12,13], while others [14,15] indicate that it is the age of 60 years and over, while, according to the United Nations suggestion, only people over 65 should be considered as seniors [16].

The standard of living is the existence of welfare level for society or individual, it relates to goods and services that people are able to consume and have approach to the resources. The concept of the "standard" may be contrasted with the quality of life which takes into account not only the material standard of living but also other various subjective factors that influence human lives such as leisure, safety, political freedom, social life, environment and the like [17]. According to Chappelow [18] a standard of living is the level of wealth, material goods, comfort, and necessities available to a certain socioeconomic class or a certain geographic area. The standard of living includes basic material factors such as income, gross domestic product (GDP), life expectancy, and economic opportunity. The standard of living is closely related to quality of life, which can also include factors such as economic and political stability, political and religious freedom, environmental quality, climate, and safety. So that the standard of living comprises objective and subjective living conditions expressed in housing affordability conditions, the level of disposable income and consumption expenditure as well as the satisfaction of both the material situation and the consumption needs. 
The article consists of six sections. After the introduction, purpose and hypothesis of the report the literature review is presented. Section 3 describes and explains the data source and the test method. Section 4 is divided into four parts: the first part presents hierarchy of one-person household types by aggregate index of living standard, the second part outlines the income situation in one-person households, the third part presents the expenditures on consumption in one-person households and the fourth part contains information about groups of one-person households of the elderly according to objective and subjective characteristics of the standard of living. Section 5 provides discussion. Finally, a conclusion of the analysis and major findings end this text.

The presented research fills the gap in the knowledge concerning the functioning of a one-person household of the elderly, and so it helps developing the theory of household economics. In the empirical aspect, the contribution of this work to economic sciences is the following: (a) the assessment of the standard of living in various types of one-person households due to the demographic and socio-economic characteristics of these households' members, (b) the indication of household types, showing the hierarchy of one-person households of the elderly as regards the achieved standard of living, and (c) selecting the types of one-person households of the elderly in terms of both financial and consumption conditions and the subjective assessments of these conditions. The novelty in this study is to identify the types of one-person households of the elderly according to standards of living.

\section{Literature Review}

\subsection{Demographic Shifts}

The population of Europeans is becoming increasingly older. The percentage of working-aged people is decreasing, and the relative number of retired people is increasing. The median age for the European Union was 39.2 in 2004, and 43.1 in 2018 (in Poland, respectively: 36.2 and 40.6). Throughout this period, the highest increase in the median age across the EU countries was observed in Romania, Lithuania and Portugal (minimum of 6 years) [19]. The number of one-person households is also increasing [20]. Generally, across the EU there is a larger number of these households among the working age (up to 60-65 years old) than the post-working age (over 65), but the growth rate is faster in the group of older people. In many countries of Central and Eastern Europe, including Poland, there are more one-person households at the retirement age than at the working age. The prevalence of "living alone" at the end of life varies widely in the world, but in all countries the growth of this part of society has been mighty in last decades, even in societies in which, traditionally, there are strong family ties [21,22]. Summarizing, among elderly persons there is an increasing trend towards independent living, and great number of older persons across the world live alone [23,24].

The growing number of one-person households of the elderly is the result of socio-demographic changes that have taken place and are still observed in human history [25]. On the one hand, the elderly persons who live alone, can be in such an experience by its own choice, aiming at independence and autonomy; on the other hand, there are individuals who live alone for lack of choice, child evasion, for long physical distances between elderly and family members, for loss of spouse [21]. The increase in the number of the elderly poses many serious social implications to a country, particularly regarding their well-being, quality of life. While there is no consensus on the implications of the economic development on the well-being of the elderly [26], the factors that affect their well-being include income, living conditions and arrangements, social contacts, as well as their physical and mental health [27].

Researchers have pointed [9] out that the number of seniors living in one-person households is expected to increase in the future. Population ageing and the growing number of one-person households of elderly people in developed countries is becoming a global social challenge that needs to be reflected in social policies worldwide. These forecasts must be taken into account by the authorities when preparing social and public policy programs $[9,28]$, because many of these people have a very low income. 


\subsection{Income and Consumption of the Elderly Households}

The growing share and the absolute number of older people running a one-person household has numerous consequences for the state policies and economic entities, and it is why this issue should be discussed in economic literature. Single elderly people are primarily of interest to researchers studying, medicine, psychology and sociology. The papers concerning these research areas raise problems of the elderly living alone and demonstrate the effects of these problems [29-31]. In economic literature, researchers from various countries view the financial situation for one-person households of the elderly as worse than for the other types of households [9].

Although the income situation among the elderly and the people running one-person households is improving, their relative poverty rate increases. The share of households of people aged 65 and over was $11.7 \%$ in 2008 and $12.8 \%$ in 2016 . The relative poverty rate of one-person households increased by $5.7 \%$, from $20.3 \%$ in 2008 to $26.0 \%$ in 2016 [32].

For every second person aged 60+ holding a one-person household in Poland, the retirement pension is the main source of income. Throughout the period 2007-2018, the real disposable income of pensioners running one-person households increased by $27.6 \%$, while consumption expenditure in real terms increased by $10.7 \%$, which shows that the financial situation of this socio-economic group improved. Changes in marginal propensity to consume (MPC) indicate that within the analyzed period the increase in consumption expenditure was generally lower than the increase the income, except for the years 2016-2017, when a slightly higher increase in consumption expenditure than in disposable income was recorded (Figure 1).

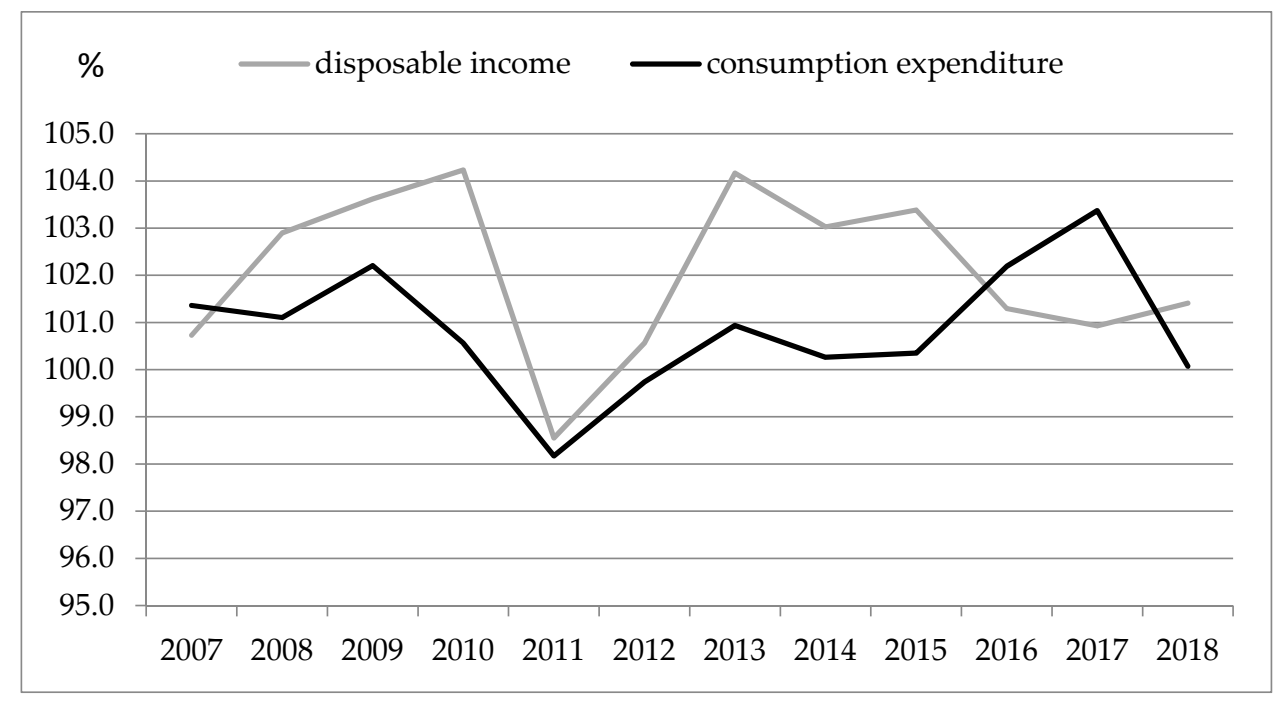

Figure 1. Dynamics of real disposable income and real consumer expenditure in one-person households of pensioners in Poland, 2007-2018. Commentary: The same adjusted general inflation rate was applied for all households. The dynamics is calculated as the quotient of nominal income (or nominal expenditure) and price indices for consumer goods and services. Source: own work on the basis of $[33,34]$.

The average propensity to consume (share of consumption expenditure in disposable income) in retirees' one-person households in the years 2006-2018 decreased with some fluctuations. Thus, at the beginning of the considered period the average propensity to consume was 0.89 , in 2012 it was 0.86, and 0.82 in 2018, which means that Polish pensioners were saving more and more. In Polish one-person households of retired, the share of expenditure on food and non-alcoholic beverages in expenditure on total consumption is decreasing, which, according to Engel's law, indicates positive changes. However, the share of these expenses is still relatively high, in 2006 the share of expenditure 
on food and non-alcoholic beverages in total consumption expenditure was $29.0 \%$, while in 2018 it was $27.6 \%$.

Income from retirement pensions is the stable form of financing the needs of household members, however the average amount of these benefits is lower than the average remuneration for work. Over $11 \%$ of households of people who have paid pension contributions to the Social Insurance Institution (contributions from people working full-time or running their own non-agricultural business activity) in Poland receive pensions in the amount equal to the social minimum (which in Poland is defined as a model allowing the minimum level for social integration of households) or below it [35-37].

A particularly disadvantageous situation is observed among people who in the past paid contributions from agricultural activities. Their pensions are below the official minimum social level. In 2019, the average pension among former farmers was PLN 1100, while the social minimum for a one-person retirement household was set at PLN 1151 [38]. The estimated pensions will be even lower in the future. Such low income in many households of the elderly, in the context of their increasing share in the total household structure, will affect the structure of production, consumption, saving and investment in the future.

The important variable affecting the different standard of living in households, is (apart from the source of income) the place of residence. The households of the elderly in rural areas are faced with problems of ensuring food security at the household level [39]. The household budget should provide the elderly not only with basic needs, but also allow them to participate in social life, use culture and leisure goods and services. A high level of social participation of older people is believed to have a positive relationship between activity and life satisfaction [40]. Low income and health problems are repeatedly the reasons for the withdrawal of older people from participation in social life.

Another variable affecting the standard of living is the gender of the person running the household. The women typically have lower wages than the men, a greater likelihood of part-time work and more career breaks, and thus generally a less complete contribution record. On average, women receive lower pensions than men. For reasons with roots both in labor markets and pension design, elderly poverty is greater among women than men [41].

One-person households of the elderly in economic literature are considered mainly from the perspective of social exclusion and poverty. On the other hand, there are also reports claiming [42] that the material status of older people is changing favorably, they are acquiring more and more goods, which is sometimes considered as consumerism. Such behavior mainly concerns better educated people living in urban areas.

The review of the Polish and worldwide literature revealed a gap in research. There is a research deficit was found that would relate analysis exclusively to one-person households of the elderly, while it seems to be obvious that this kind of households may be different from the multi-person households. The lack of research is also confirmed by other researchers [21]. For example, in the household run by one person, as a rule, there is no dependence on other people during making decisions about the amount of expenditures on particular categories of goods and services, and financial resources are not combined with other people. Identifying the types of these households and their standard of living is extremely important due to their increasing share in the total number of households.

\section{Conception of Analysis and Test Method}

The study was focused on one-person households of the elderly in Poland. The research material was represented by the statistical data from individual, unpublished Central Statistic Office (CSO) data for household budget investigations in 2016, that covered over 37,000 households. There were 4971 one-person households of elderly people in 2016 [43]. So, the sample for this study was selected based on the following three variables: age (60+), household size (one person), and a country (Poland).

Statistical data analyses were performed using Statistica software version 13.0. The study includes:

- Descriptive measures: arithmetic mean, median and asymmetry factor to examine the distribution of disposable income and consumption expenditure; 
- $\quad$ Statistical methods:

- Aggregate standard of living to examine the standard of living in the types of households;

- Reliability analysis and Cronbach's alpha coefficient to examine the quality / accuracy of the created standard of living measurement;

- Analysis of variance and post-hoc tests to show statistically significant differences between the analyzed types of households;

- Cluster analysis: Ward and k-mean to create groups of households with similar characteristics due to the objective material and consumption situation as well as subjective feelings of the financial situation and satisfying consumption needs.

There is no consensus on the method of constructing living standards measures [44]. In the literature on the subject, for measurement the living standard are applied such indicators as Sen's Capability Approach [45], the utility-based living standards [46] and others. In this paper, to evaluate the standard of living in one-person households of people aged 60 and over, an aggregate (composite) indicator (AI) was designed. The aggregate indicator of the life quality based on the index of Economic Living Standard Index (ELSI) [47]. ELSI was constructed to assess social exclusion and to measure social dimension of life quality, not only the financial aspects of life. The use of this indicator in other studies of living standards has proved effective.

To design the indicator, the variables were transformed in such a way that they all were stimulants, i.e., larger values of a given variable positively correlated with the synthetic feature, i.e., a more advantageous standard of living. The differential transformation is described using Equation (1). Both objective and subjective social indicators have been taken into consideration.

$$
x_{\mathrm{ij}}^{\prime}=1 / x_{\mathrm{ij}}
$$

where $x_{\mathrm{ij}}$ - is the value of the $i$-th implementation of the $j$-th variable in the form of anti-stimulants.

The first group included the following objective indicators: the level of disposable income, the level of expenditure on consumption, the level of expenditure on: food and non-alcoholic beverages, housing and energy sources, housing equipment, education, culture and leisure, clothing and footwear, health protection, transport and communication, catering and accommodation, other consumer goods and services, housing conditions (e.g., whether the dwelling place has a kitchen, the access to hot water, whether it is not damp, etc.).

In the other group, concerning the subjective social indicators, the following factors were taken into consideration: the subjective assessment of the building, the assessment of financial situation and the assessment of its improvement, the assessment of the satisfaction of needs and the housing conditions (Equation (2)).

$$
\mathrm{AI}=w_{\mathrm{O}}+w_{\mathrm{S}}
$$

where:

AI - the aggregate (composite) indicator,

$w_{o}$ - objective variables of living standards,

$w_{s}$ - subjective variables of living standards.

While determining the aggregate indicator for the standard of living, the division of households with regard to the level of expenditure was determined arbitrarily, using the amounts of expenditure in the minimum subsistence basket. It was found that expenditure below the level stated in the minimum subsistence basket qualified a given household to be marked with a value 0 . The households with expenses up to double the amount of expenditure defined in the minimum subsistence basket were assumed to be assigned a value of 1 . Households with expenses above twice as high as in the minimum subsistence basket were assumed to have an evaluation charge equal 2. Such evaluation of households is subjective, but it results from the performed assessment of the significance of the need satisfying. 
The adopted divisions of households are justified both statistically and substantively, although they are only arbitrary.

The designed aggregate indicator for the standard of living was verified by analyzing the correlations between its components. For this purpose, reliability analysis was applied. The reliability analysis assesses the accuracy with which a given scale (aggregate indicator for the standard of living) measures a given phenomenon [48,49]. The standard of living scale included 42 items. Objective and subjective assessments of the household functioning were found on the scale. Objective factors include income, expenditure, home infrastructure and housing conditions, while subjective factors assess how the people perceive their income situation, meet their needs and to what extent they are satisfied with their housing conditions.

An average of 49.50 was obtained from the summing of scale statistics, with a standard deviation of 10.97 and a variance of 120.40. The Cronbach's alpha coefficient (a measure of internal scale consistency (mathematical formula no. 3)) was 0.72 , while the standardized alpha was 0.76 . Cronbach's alpha coefficient takes values from 0 to 1 ; the value above 0.7 means fair reliability of the scale $[50,51]$. Considering the fact that all correlations were positive and basing on the obtained reliability coefficients, it was assumed that the indicator is internally consistent, and its individual components represent a mapping of elements of one phenomenon determining living conditions and the satisfaction of the needs of one-person households.

The formula for Cronbach's alpha is the following (Equation (3)):

$$
\text { Cronbach's } s=\mathrm{N} \times \overline{\mathrm{c}} / \overline{\mathrm{v}}+(\mathrm{N}-1) \times \overline{\mathrm{c}}
$$

where:

$\mathrm{N}$ - the number of items,

$\overline{\mathrm{c}}$-average covariance between item-pairs,

$\overline{\mathrm{v}}$-average variance.

The simulation showed that the raising of the Cronbach's Alpha index 0.90 would be associated with adding 10 new test items. Insertion of durable goods were also considered. However, it was stated that at present, the lack of certain durable goods does not have to be associated with a lower standard of living, but just with no need to possess these goods. For example, a great number of consumers do not have a TV, claiming that it is replaced by a computer with internet access (the share of people running a one-person household who have a TV decreased by 2.6 percentage points), or a microwave oven, claiming that the products prepared in it are not beneficial to health. The higher are the levels of indicators obtained, the more advantageous living conditions and a greater satisfaction with meeting needs can be expected.

In order to analyze statistically significant differences in the level of the aggregate indicators of life quality between types of households, analysis of variance was used. The research hypothesis assumed that the mean values of the aggregate indicator for the standard of living in the types of one-person elderly households are the same, while the alternative hypothesis put forward that at least two mean values of the aggregate indicator for the standard of living in these types of elderly households are different.

If the analysis of variance showed statistically significant differences $(p<0.05$, significance level $\alpha=0.05$ ) between the considered means, post-hoc tests were used to find the answer the question which of the $n$ means are significantly different from each other. For unequal sample sizes the Tukey's range test (Tukey's honestly significant difference, HSD) was used. This test is most recommended for comparisons of pairwise differences between factor level means [52]. It is worth noting that, in testing statistical hypotheses, the significance level $\alpha$ plays an important role. By means of the $\alpha$, the probability of rejecting the true hypothesis is determined at the desired level. This probability is exactly equal to the $\alpha$ value only for a single application of the statistical test. With multiple comparison of average value pairs, there is a certain cumulative level of significance, greater than $\alpha$, and it is a proper 
characteristic of the probability for false rejection of at least one of the true hypotheses telling about the equality of the average values compared.

Ward's and k-means grouping methods make possible to establish the number of households' groups. More information on cluster methods can be found in [53]. First, Ward's analysis was applied so as to obtain information on the number of emerging groups of one-person households of the elderly. The applied criterion was the first significant leap in agglomeration distance [54,55]. The dendrogram was cut-off on the level of 17 , and, as a result, four groups were created. Then k-means analysis was performed for these groups.

\section{Results}

\subsection{Standard of Living Based on the Aggregate Indicator of Living Standards}

The standard of living is a complex concept that combines objective and subjective measurable and immeasurable, quantitative and qualitative features [56]. The methodological problem of assessing the standard of living leads, among other things, to determining what aspects of life should be taken into account, what indicators should characterize them, what aggregation function should be used to determine the synthetic indicator, and also what threshold values should be used to identify individuals with high and low standard of living.

The study uses a summary description of the functioning of the households of the elderly, constructing for this purpose an aggregate indicator of the standard of living. Research results prove that the highest standard of living is characteristic for people aged $60+$, white-collar employers or self-employed (Table 1). The standard of living in the households of these two social groups was statistically significantly different from the standard of living in the other socio-economic groups. Changes in economic activities during the transition from working-age to the post-productive age have a major impact on the standard of living for people working mentally and running their own business. The standard of living in households of white-collar workers and self-employed persons was higher than in households of retirees and pensioners (the difference in the number of points between households was at least 10). The p-value from the one-way analysis of variance between the aggregate indicator value and the socio-economic group was below $0.05(\alpha=0.05)$.

Higher educated people had also a high standard of living. Their standard of living was statistically significantly (one-way analysis of variance, $p<0.05, \alpha=0.05$ ) higher in comparison to the people with a lower level of education. A relatively high standard of living was also achieved in households of people living in cities of over 100,000 inhabitants. Living standards in households located in cities with a population of 100,000 and more were statistically significantly higher than in households from smaller settlements. It was noticed the greatest increase in the standard of living, on a point scale by 3.9 points takes place after the movement a person from the group living in the rural area to a group living in the town with a population of less than 20,000.

However, the transition from a group of people living in the smallest towns to a group of people living in cities with a population of 20-99 thousand increases the standard of living by 1 percentage point only. People with secondary or post-secondary education had a relatively high standard of living. The standard of living in these households was significantly different from other types of households grouped on the basis of the education level. In terms of percentage points, the standard of living in these households reached 51.8, while in the households of people with higher education it was 60.0 points. The calculations show that the standard of living increases mainly as a result of the transition from the group with secondary or post-secondary education to the group of people with higher education - an increase in the standard of living by 8.2 points. However, the transition from the group of people with basic vocational education to the group of people with secondary or post-secondary education increases the standard of living by 5.2 points, and the transition from the group of people holding lower secondary education diplomas to the group of people holding basic vocational education diplomas increases the standard of living by $2-5$ points. 
Table 1. The value of the aggregate indicator of the standard of living by the type of one-person households of the elderly.

\begin{tabular}{|c|c|c|}
\hline $\begin{array}{l}\text { Type of One-Person Households of Elderly } \\
\text { People }\end{array}$ & Value of the Aggregate Indicator & Number of Households (N) \\
\hline Total one-person households of elderly people & 49.5 & 4971 \\
\hline $\begin{array}{l}\text { Socioeconomic groups: Households of } \\
\text { white-collar workers }\end{array}$ & 62.1 & 127 \\
\hline Educational level: Higher & 60.0 & 658 \\
\hline $\begin{array}{l}\text { Socioeconomic groups: Households of } \\
\text { self-employed }\end{array}$ & 60.0 & 39 \\
\hline $\begin{array}{l}\text { Place of localization: City } 500 \text { thousand and } \\
\text { more inhabitants }\end{array}$ & 53.2 & 774 \\
\hline $\begin{array}{l}\text { Educational level: Secondary and } \\
\text { post-secondary }\end{array}$ & 51.8 & 1789 \\
\hline $\begin{array}{c}\text { Place of localization: City 200-499 thousand } \\
\text { inhabitants }\end{array}$ & 51.8 & 557 \\
\hline $\begin{array}{c}\text { Place of localization: City 100-199 thousand } \\
\text { inhabitants }\end{array}$ & 51.3 & 487 \\
\hline Marital status: Married & 51.2 & 156 \\
\hline Region of Poland: Southwestern & 51.2 & 579 \\
\hline Professionally inactive people & 51.1 & 3128 \\
\hline Region of Poland: Southern & 50.8 & 973 \\
\hline $\begin{array}{c}\text { Place of localization: City } 20-99 \text { thousand } \\
\text { inhabitants }\end{array}$ & 50.4 & 1033 \\
\hline Marital status: Divorced & 50.3 & 610 \\
\hline Region of Poland: Central & 50.0 & 1118 \\
\hline Gender: Female & 49.8 & 3872 \\
\hline $\begin{array}{l}\text { Socioeconomic groups: Households of } \\
\text { retirees }\end{array}$ & 49.8 & 3744 \\
\hline Marital status: Widow, widower & 49.6 & 3674 \\
\hline $\begin{array}{c}\text { Place of localization: Town below } 20 \\
\text { thousand inhabitants }\end{array}$ & 49.5 & 606 \\
\hline Region of Poland: Northern & 49.1 & 716 \\
\hline $\begin{array}{l}\text { Socioeconomic groups: Households of } \\
\text { pensioners }\end{array}$ & 48.5 & 841 \\
\hline Gender: Male & 48.3 & 1099 \\
\hline Marital status: In separation & 48.2 & 49 \\
\hline Region of Poland: Northwest & 48.1 & 744 \\
\hline Region of Poland: Eastern & 47.7 & 841 \\
\hline Marital status: Unmarried, never married & 47.0 & 482 \\
\hline Educational level: Basic vocational & 46.6 & 1070 \\
\hline Professionally active people & 46.5 & 1843 \\
\hline Place of localization: Countryside & 45.6 & 1514 \\
\hline $\begin{array}{l}\text { Socioeconomic groups: Households of } \\
\text { blue-collar workers }\end{array}$ & 45.2 & 72 \\
\hline $\begin{array}{c}\text { Educational level: Lower secondary, primary } \\
\text { or less }\end{array}$ & 44.0 & 1454 \\
\hline $\begin{array}{l}\text { Socioeconomic groups: Households living on } \\
\text { supplementary welfare allowance }\end{array}$ & 43.8 & 32 \\
\hline $\begin{array}{l}\text { Socioeconomic groups: Households of } \\
\text { farmers }\end{array}$ & 41.7 & 23 \\
\hline $\begin{array}{l}\text { Socioeconomic groups: Households having } \\
\text { income from other sources }\end{array}$ & 31.2 & 93 \\
\hline
\end{tabular}


The research also showed statistically significant (one-way analysis of variance, $p<0.05, \alpha=0.05$ ) differences in the living standard between women and men aged 60+ running one-person households. Women had a slightly higher standard of living (49.8 points) compared to men (48.3 points), which is also confirmed by the results of research for all one-person households [57].

Statistically significant (one-way analysis of variance, $p<0.05, \alpha=0.05$ ) differences in the standard of living were also noticed between economically active and inactive people. It turned out that professionally active people had a lower standard of living ( 47.0 points) compared to inactive people (51.1 points). This is quite an interesting result, because retirement is usually associated with a reduction in income levels. In one-person households, it was observed [57] that the level of disposable income declined with age. On the other hand, leaving work can be associated with stress reduction and enjoying the possession, hence a higher standard of living in the households of professionally inactive people.

It also happens that one-person households are run by married people who manage their household budget separately. Older people who want to maintain their independence in terms of budget and property, consciously undertake to run a one-person household, despite being in a relationship with a partner [58]. With regard to these households, the highest standard of living (51.2 points) was demonstrated, divorced persons had a slightly lower standard of living (50.3 points), and even lower for widowed persons (49.6 points), although no statistically significant differences in the standard of living were noted for these households. The lowest standard of living was characteristic of people who were never married. Among these people the average standard of living on a point scale was 47.0 points. Furthermore, it was statistically significantly (Tukey range test) different from the other groups by marital status. This is quite a surprising fact, since in the author's earlier research [57], the standard of living for the never-married running one-person households was higher than among the other types of one-person households (by marital status).

The lowest living standard was observed among people $60+$ living on social benefits, as well as among farmers in the rural area, living on sources of revenue not related to paid work performed and having at best lower secondary education. The standard of living in the group of people living on social benefits other than retirement or disability pensions was statistically significantly different from the standard of living in the other socio-economic groups.

Based on the presented results regarding the standard of living in one-person households of persons aged 60 and over, it is worth taking a deeper look at the income and consumption situation in households with the highest and lowest standard of living. The indicators of selected objective and subjective features that characterize the standard of living in households are presented below.

\subsection{Income Situation in One-Person Households of People 60+}

The income situation of the elderly is diversified. The socio-economic group and the level of education affect this situation significantly. Considering the income situation in one-person households of the elderly, the following should be stated. The white-collar employers or the self-employed had the most favorable income situation. People with higher education also had relatively high incomes. People living in larger cities, i.e., with the number of inhabitants over 500 thousand and, farther, from 200 thousand up to 499 thousand, had next positions in terms of disposable income (Table 2). 
Table 2. Arithmetic mean and median of disposable income and subjective assessment of the material situation in one-person households of the elderly in Poland (variables ordered by an aggregate indicator of the standard of living).

\begin{tabular}{|c|c|c|c|c|}
\hline $\begin{array}{c}\text { Type of One-Person Households } \\
\text { of Elderly People }\end{array}$ & $\begin{array}{l}\text { Arithmetic } \\
\text { Mean }\end{array}$ & Median & Asymmetry Index & $\begin{array}{c}\text { Subjective } \\
\text { Assessment of the } \\
\text { Material Situation * }\end{array}$ \\
\hline $\begin{array}{l}\text { Socioeconomic groups: } \\
\text { Households of white-collar } \\
\text { workers }\end{array}$ & 3962 & 3050 & 2.14 & 2.3 \\
\hline Educational level: Higher & 2813 & 2382 & 3.97 & 2.4 \\
\hline $\begin{array}{c}\text { Socioeconomic groups: } \\
\text { Households of self-employed }\end{array}$ & 3210 & 2500 & 0.52 & 2.3 \\
\hline $\begin{array}{l}\text { Place of localization: City } 500 \\
\text { thousand and more inhabitants }\end{array}$ & 2267 & 1934 & 5.05 & 2.9 \\
\hline $\begin{array}{l}\text { Educational level: Secondary and } \\
\text { post-secondary }\end{array}$ & 1896 & 1773 & 2.07 & 2.9 \\
\hline $\begin{array}{l}\text { Place of localization: City 200-499 } \\
\text { thousand inhabitants }\end{array}$ & 2036 & 1833 & 2.68 & 3.0 \\
\hline $\begin{array}{c}\text { Place of localization: City 100-199 } \\
\text { thousand inhabitants }\end{array}$ & 1960 & 1792 & 2.30 & 2.9 \\
\hline Marital status: Married & 2150 & 1897 & 4.95 & 2.9 \\
\hline $\begin{array}{l}\text { Place of localization: City 20-99 } \\
\text { thousand inhabitants }\end{array}$ & 1829 & 1679 & 2.62 & 3.0 \\
\hline Marital status: Divorced & 1999 & 1698 & 4.13 & 3.0 \\
\hline Gender: Female & 1783 & 1604 & 5.17 & 3.0 \\
\hline $\begin{array}{l}\text { Socioeconomic groups: } \\
\text { Households of retirees }\end{array}$ & 1787 & 1634 & 4.18 & 3.0 \\
\hline Marital status: Widow, widower & 1787 & 1626 & 4.68 & 3.0 \\
\hline $\begin{array}{l}\text { Place of localization: City below } \\
20 \text { thousand inhabitants }\end{array}$ & 1738 & 1604 & 2.70 & 3.0 \\
\hline $\begin{array}{l}\text { Socioeconomic groups: } \\
\text { Households of pensioners }\end{array}$ & 1685 & 1586 & 1.67 & 3.0 \\
\hline Gender: Male & 1941 & 1774 & 4.06 & 3.0 \\
\hline Marital status: In separation & 2080 & 1610 & 5.52 & 3.3 \\
\hline $\begin{array}{l}\text { Marital status: Unmarried, never } \\
\text { married }\end{array}$ & 1690 & 1543 & 1.36 & 3.1 \\
\hline $\begin{array}{l}\text { Educational level: Basic } \\
\text { vocational }\end{array}$ & 1618 & 1540 & 0.90 & 3.2 \\
\hline Place of localization: Countryside & 1488 & 1366 & 1.85 & 3.2 \\
\hline $\begin{array}{c}\text { Socioeconomic groups: } \\
\text { Households of blue-collar workers }\end{array}$ & 1939 & 1800 & 0.68 & 3.4 \\
\hline $\begin{array}{l}\text { Educational level: Lower } \\
\text { secondary, primary or less }\end{array}$ & 1419 & 1355 & 1.81 & 3.3 \\
\hline $\begin{array}{c}\text { Socioeconomic groups: } \\
\text { Households living on } \\
\text { supplementary welfare allowance }\end{array}$ & 1841 & 1485 & 2.12 & 3.4 \\
\hline $\begin{array}{l}\text { Socioeconomic groups: } \\
\text { Households of farmers }\end{array}$ & 975 & 720 & 0.24 & 3.3 \\
\hline $\begin{array}{l}\text { Socioeconomic groups: } \\
\text { Households having income from } \\
\text { other sources }\end{array}$ & 881 & 777 & 4.55 & 4.3 \\
\hline
\end{tabular}

Commentary: * a subjective assessment of the material situation on a five-point scale, where: 1—very good, 5-very bad. Source: own work on the basis of [43]. 
The high asymmetry index in the distribution of disposable income in most types of households indicates the necessity to use, while stating amount of income, the level of the median rather than the arithmetic mean, as the latter value is overestimated in this case. In turn, farmers and people living on social benefits other than retirement or disability pensions, had the worst income situation.

It was also noted that for these two types of households with the lowest incomes, the level of these incomes was lower than the social minimum fixed for one-person households, which may be a premise for the exclusion of people with such low income from many spheres of life.

Low income was reflected in subjective low assessments of material situation (Table 2). It was also noted that in some types of households, although they had relatively high incomes, low ratings of material situation were pointed out (for example, one-person households with person in separation, one-person households of blue-collar workers).

On the other hand, elderly people with permanent retirement benefits have relatively greater financial security compared to younger working age people. The lower risk of pauperization among seniors households is consistent with research suggestion saying that the public pensions provided to people $65+$ are protective for them and offer them financial security $[6,59]$. The level of disposable income in one-person households of people aged 60+ compared to other types of households is presented in Table 3.

Table 3. Comparison of disposable income and assessment of the material situation in one-person households and multi-person households in Poland.

\begin{tabular}{ccccc}
\hline Type of Households & $\begin{array}{c}\text { Arithmetic } \\
\text { Mean }\end{array}$ & Median & Asymmetry Index & $\begin{array}{c}\text { Subjective } \\
\text { Assessment of the } \\
\text { Material Situation * }\end{array}$ \\
\hline $\begin{array}{c}\text { One-person households with } \\
\text { people aged 60 and over }\end{array}$ & 1818 & 1633 & 4.9 & 3.0 \\
\hline $\begin{array}{c}\text { One-person households with } \\
\text { people under 60 years of age }\end{array}$ & 2499 & 2085 & 35.9 & 2.6 \\
\hline $\begin{array}{c}\text { Households of two and more } \\
\text { people }\end{array}$ & 1560 & 1373 & 4.7 & 2.8 \\
\hline
\end{tabular}

Commentary: * a subjective assessment of the material situation on a five-point scale, where: 1-very good, 5-very bad. Source: own work on the basis of [43].

\subsection{Consumption in One-Person Households of 60+}

Turning to the analysis of expenditure on consumption in one-person households aged 60+, it should be stated that the level of these expenses directly reflects the level of disposable income. The most favorable consumption situation concerns the households of white-collar employers or the self-employed, i.e., those with the highest income. The lowest share of expenditure on food and non-alcoholic beverages in disposable income gives these households great opportunities to meet higher-order needs.

In households of white-collar employers, the share of expenditure on food and non-alcoholic beverages accounted for $13.1 \%$, and together with expenditure on housing maintenance, the share of these expenses did not exceed one third of total disposable income (Table 4). The situation was similar in the households of self-employed people. In both socio-economic groups, the share of expenditure on higher-order needs, including culture and leisure, was the highest among all groups and represented about $8 \%$ of total disposable income. 
Table 4. Percentage of expenditure on categories of consumer goods and services in disposable income in one-person household types with the highest and lowest standard of living (objective characteristics) (variables ordered by an aggregate indicator of the standard of living).

\begin{tabular}{|c|c|c|c|c|c|c|c|c|}
\hline Specification & Basic Goods & $\begin{array}{c}\text { Alcoholic } \\
\text { Beverages and } \\
\text { Tobacco } \\
\text { Products }\end{array}$ & $\begin{array}{c}\text { Clothing, } \\
\text { Footwear and } \\
\text { Apartment } \\
\text { Equipment }\end{array}$ & $\begin{array}{l}\text { Transport and } \\
\text { Communications }\end{array}$ & Health & $\begin{array}{l}\text { Culture, } \\
\text { Recreation } \\
\text { and Education }\end{array}$ & $\begin{array}{l}\text { Catering and } \\
\text { Accommodation }\end{array}$ & $\begin{array}{l}\text { Other Goods } \\
\text { and Services }\end{array}$ \\
\hline & \multicolumn{8}{|c|}{ Percent in Disposable Income } \\
\hline $\begin{array}{l}\text { Socioeconomic groups: Households of } \\
\text { white-collar workers }\end{array}$ & 28.8 & 2.7 & 7.4 & 8.8 & 4.5 & 8.1 & 3.6 & 8.5 \\
\hline Educational level: Higher & 36.4 & 2.0 & 3.4 & 9.5 & 8.7 & 7.5 & 4.2 & 7.2 \\
\hline $\begin{array}{l}\text { Socioeconomic groups: Households of } \\
\text { self-employed }\end{array}$ & 32.5 & 2.6 & 7.6 & 10.6 & 10.3 & 7.7 & 5.5 & 4.2 \\
\hline $\begin{array}{l}\text { Educational level: Secondary or } \\
\text { post-secondary }\end{array}$ & 44.7 & 1.9 & 3.2 & 8.1 & 8.0 & 5.0 & 4.3 & 6.3 \\
\hline Gender: Female & 46.1 & 1.4 & 7.2 & 6.1 & 8.6 & 4.9 & 4.0 & 6.1 \\
\hline $\begin{array}{l}\text { Socioeconomic groups: Households of } \\
\text { retirees }\end{array}$ & 45.6 & 1.8 & 6.3 & 7.3 & 8.3 & 4.7 & 4.2 & 5.6 \\
\hline $\begin{array}{l}\text { Socioeconomic groups: Households of } \\
\text { pensioners }\end{array}$ & 48.5 & 1.7 & 7.5 & 5.2 & 8.6 & 4.2 & 4.0 & 6.3 \\
\hline Gender: Male & 41.6 & 3.8 & 4.6 & 11.0 & 6.0 & 4.7 & 5.0 & 4.9 \\
\hline Educational level: Basic vocational & 49.0 & 2.3 & 3.4 & 6.8 & 6.7 & 3.8 & 4.0 & 4.8 \\
\hline $\begin{array}{l}\text { Socioeconomic groups: Households of } \\
\text { blue-collar workers }\end{array}$ & 39.5 & 5.7 & 6.7 & 17.7 & 2.8 & 3.9 & 3.7 & 5.0 \\
\hline $\begin{array}{l}\text { Educational level: Lower secondary, } \\
\text { primary or less }\end{array}$ & 50.3 & 1.5 & 4.7 & 4.3 & 8.5 & 3.0 & 4.2 & 4.6 \\
\hline $\begin{array}{l}\text { Socioeconomic groups: Households } \\
\text { living on supplementary welfare } \\
\text { allowance }\end{array}$ & 48.2 & 3.1 & 7.7 & 10.4 & 5.2 & 8.2 & 5.4 & 5.1 \\
\hline $\begin{array}{l}\text { Socioeconomic groups: Households of } \\
\text { farmers }\end{array}$ & 80.0 & 3.4 & 7.0 & 17.4 & 4.1 & 4.8 & 4.6 & 5.5 \\
\hline $\begin{array}{l}\text { Socioeconomic groups: Households } \\
\text { having income from other sources }\end{array}$ & 61.2 & 5.7 & 4.9 & 6.9 & 7.5 & 2.4 & 8.0 & 3.7 \\
\hline
\end{tabular}

Commentary: Basic goods consist of: food, non-alcoholic beverages and housing, water, electricity, gas, other fuels. Source: own work on the basis of [43] . 
At the other end of the scale in terms of consumption were one-person households of farmers and persons living on other social benefits. For these households, the share of expenditure on food and housing maintenance exceeded $60 \%$ of disposable income. Basic needs (food and housing maintenance) also consumed half of the disposable income in the households of people with the lowest level of education.

The high share of expenses for basic needs depleted expenses for higher level needs. The share of expenditure on culture and leisure for the households of people living on social benefits accounted for $2.4 \%$, and $3.0 \%$ for the households of people with the lowest level of education. It is also worth noting that spending on culture and leisure was characterized by a high asymmetry rate, which indicates that more than half of households spent less on culture and leisure as compared to the average.

Health care expenditure is an important item in older households. In the older age, the incidence of chronic diseases increases, which leads to an increase in health care costs, including those 'out of pocket'. Depending on the type of household, the share of health expenditure in disposable income ranged from about $4 \%$ to over $10 \%$. A relatively low share of expenditure on health was recorded in farmers' households, which is probably caused by a significant financial impact on the household budget with basic needs (food, housing maintenance) and the inability to use private healthcare for financial reasons. A difficult material situation, which is reflected in consumption, is observed in farmers' households in the case of expenditure on higher-order goods and services (culture, leisure, education, gastronomy, accommodation).

Based on a comparison of the percentage of expenditure in disposable income between one-person households of persons aged 60+ and one-person households of young people and multi-person households, the following can be stated (Table 5). In one-person households with people aged 60 and over a high percentage of expenditure on basic goods, i.e., food, housing, health was recorded. In turn, the percentage of expenditure on other consumer goods and services was low, which may indicate exclusion of elderly people from certain areas of life.

Comparisons of meeting consumer needs in various types of one-person households with people aged 60 and more are presented in Table 6. Low satisfaction of needs applies mainly to services: culture, education and training, tourism and recreation. A relatively high satisfaction of consumption needs was observed in households of: white-collar workers, self-employed, people with higher education and households located in city 500 thousand and more inhabitants.

The assessment of meeting the needs in one-person households with people aged 60 and over is worse than in one-person households of younger people and multi-person households (Table 7). 
Table 5. Expenditure on categories of consumer goods and services in disposable income in one-person households and multi-person households in Poland (variables ordered by an aggregate indicator of the standard of living).

\begin{tabular}{|c|c|c|c|c|c|c|c|c|}
\hline Specification & Basic Goods & $\begin{array}{c}\text { Alcoholic } \\
\text { Beverages and } \\
\text { Tobacco } \\
\text { Products }\end{array}$ & $\begin{array}{c}\text { Clothing, } \\
\text { Footwear and } \\
\text { Apartment } \\
\text { Equipment }\end{array}$ & $\begin{array}{l}\text { Transport and } \\
\text { Communications }\end{array}$ & Health & $\begin{array}{c}\text { Culture, } \\
\text { Recreation } \\
\text { and Education }\end{array}$ & $\begin{array}{l}\text { Catering and } \\
\text { Accommodation }\end{array}$ & $\begin{array}{l}\text { Other Goods } \\
\text { and Services }\end{array}$ \\
\hline & \multicolumn{8}{|c|}{ Percent in Disposable Income } \\
\hline $\begin{array}{l}\text { One-person households with people } \\
\text { aged } 60 \text { and over }\end{array}$ & 45.1 & 1.9 & 6.6 & 7.3 & 8.0 & 4.8 & 4.2 & 5.8 \\
\hline $\begin{array}{l}\text { One-person households with people } \\
\text { under } 60 \text { years of age }\end{array}$ & 36.1 & 2.9 & 7.8 & 12.8 & 3.3 & 6.2 & 7.1 & 5.1 \\
\hline Households of two and more people & 33.5 & 2.0 & 8.2 & 10.5 & 4.3 & 5.7 & 2.9 & 6.0 \\
\hline
\end{tabular}

Source: own work on the basis [43]

Table 6. Subjective assessments of the satisfaction of consumption needs in one-person households of the elderly in Poland (variables ordered by an aggregate indicator of the standard of living).

\begin{tabular}{|c|c|c|c|c|c|c|c|c|}
\hline \multirow[b]{2}{*}{$\begin{array}{l}\text { Types of One-Person Households of the } \\
\text { Elderly }\end{array}$} & \multicolumn{8}{|c|}{ Satisfying Consumer Needs in Terms of: } \\
\hline & Food Products & $\begin{array}{l}\text { Clothing and } \\
\text { Footwear }\end{array}$ & Health Care & $\begin{array}{l}\text { Timely } \\
\text { Payment of } \\
\text { Housing } \\
\text { Charges }\end{array}$ & $\begin{array}{l}\text { Furnishing the } \\
\text { Flat with } \\
\text { Furniture and } \\
\text { Durable } \\
\text { Goods }\end{array}$ & Culture & $\begin{array}{l}\text { Education and } \\
\text { Training }\end{array}$ & $\begin{array}{c}\text { Tourism and } \\
\text { Recreation } \\
\text { Outside the } \\
\text { Place of } \\
\text { Residence }\end{array}$ \\
\hline $\begin{array}{l}\text { Socioeconomic groups: Households of } \\
\text { white-collar workers }\end{array}$ & 1.5 & 1.8 & 2.0 & 1.4 & 2.1 & 2.4 & 5.8 & 2.7 \\
\hline Educational level: Higher & 1.7 & 2.0 & 2.1 & 1.5 & 2.2 & 2.6 & 5.7 & 3.1 \\
\hline $\begin{array}{l}\text { Socioeconomic groups: Households of } \\
\text { self-employed }\end{array}$ & 1.6 & 1.8 & 1.9 & 1.8 & 2.2 & 2.6 & 5.3 & 2.8 \\
\hline $\begin{array}{l}\text { Place of localization: City } 500 \text { thousand } \\
\text { and more inhabitants }\end{array}$ & 2.1 & 2.5 & 2.5 & 1.6 & 2.5 & 3.4 & 5.8 & 3.6 \\
\hline $\begin{array}{l}\text { Educational level: Secondary and } \\
\text { post-secondary }\end{array}$ & 2.1 & 2.5 & 2.5 & 1.7 & 2.6 & 3.5 & 5.9 & 3.9 \\
\hline $\begin{array}{l}\text { Place of localization: City 200-499 } \\
\text { thousand inhabitants }\end{array}$ & 2.0 & 2.5 & 2.6 & 1.7 & 2.7 & 3.5 & 5.8 & 3.9 \\
\hline $\begin{array}{l}\text { Place of localization: City 100-199 } \\
\text { thousand inhabitants }\end{array}$ & 2.2 & 2.5 & 2.5 & 1.8 & 2.6 & 3.7 & 5.9 & 4.0 \\
\hline Marital status: Married & 2.2 & 2.4 & 2.7 & 1.9 & 2.5 & 3.7 & 5.8 & 3.8 \\
\hline
\end{tabular}


Table 6. Cont.

\begin{tabular}{|c|c|c|c|c|c|c|c|c|}
\hline \multirow[b]{2}{*}{$\begin{array}{l}\text { Types of One-Person Households of the } \\
\text { Elderly }\end{array}$} & \multicolumn{8}{|c|}{ Satisfying Consumer Needs in Terms of: } \\
\hline & Food Products & $\begin{array}{l}\text { Clothing and } \\
\text { Footwear }\end{array}$ & Health Care & $\begin{array}{c}\text { Timely } \\
\text { Payment of } \\
\text { Housing } \\
\text { Charges }\end{array}$ & $\begin{array}{l}\text { Furnishing the } \\
\text { Flat with } \\
\text { Furniture and } \\
\text { Durable } \\
\text { Goods }\end{array}$ & Culture & $\begin{array}{l}\text { Education and } \\
\text { Training }\end{array}$ & $\begin{array}{c}\text { Tourism and } \\
\text { Recreation } \\
\text { Outside the } \\
\text { Place of } \\
\text { Residence }\end{array}$ \\
\hline $\begin{array}{l}\text { Place of localization: City } 20-99 \text { thousand } \\
\text { inhabitants }\end{array}$ & 2.1 & 2.5 & 2.6 & 1.8 & 2.7 & 3.7 & 5.9 & 4.1 \\
\hline Marital status: Divorced & 2.2 & 2.6 & 2.6 & 1.9 & 2.7 & 3.4 & 5.9 & 3.8 \\
\hline Gender: Female & 2.1 & 2.6 & 2.6 & 1.8 & 2.7 & 3.7 & 5.9 & 4.2 \\
\hline $\begin{array}{l}\text { Socioeconomic groups: Households of } \\
\text { retirees }\end{array}$ & 2.1 & 2.6 & 2.5 & 1.8 & 2.7 & 3.8 & 5.9 & 4.2 \\
\hline Marital status: Widow, widower & 2.1 & 2.6 & 2.5 & 1.8 & 2.7 & 3.8 & 5.9 & 4.3 \\
\hline $\begin{array}{l}\text { Place of localization: City below } 20 \\
\text { thousand inhabitants }\end{array}$ & 2.1 & 2.5 & 2.4 & 1.8 & 2.8 & 3.8 & 5.9 & 4.2 \\
\hline $\begin{array}{l}\text { Socioeconomic groups: Households of } \\
\text { pensioners }\end{array}$ & 2.2 & 2.6 & 2.6 & 1.8 & 2.8 & 3.9 & 5.9 & 4.4 \\
\hline Gender: Male & 2.2 & 2.5 & 2.6 & 1.9 & 2.8 & 3.9 & 5.9 & 4.2 \\
\hline Marital status: In separation & 2.2 & 2.6 & 2.8 & 2.0 & 2.9 & 4.0 & 5.9 & 4.1 \\
\hline Marital status: Unmarried, never married & 2.2 & 2.7 & 2.7 & 2.0 & 3.0 & 3.8 & 5.9 & 4.3 \\
\hline Educational level: Basic vocational & 2.2 & 2.7 & 2.8 & 2.0 & 2.9 & 4.0 & 5.9 & 4.4 \\
\hline Place of localization: Countryside & 2.2 & 2.7 & 2.6 & 2.1 & 3.0 & 4.2 & 5.9 & 4.7 \\
\hline $\begin{array}{l}\text { Socioeconomic groups: Households of } \\
\text { blue-collar workers }\end{array}$ & 2.4 & 2.9 & 2.9 & 2.2 & 3.0 & 4.2 & 6.0 & 4.2 \\
\hline $\begin{array}{l}\text { Educational level: Lower secondary, } \\
\text { primary or less }\end{array}$ & 2.3 & 2.8 & 2.7 & 2.0 & 3.1 & 4.5 & 5.9 & 4.9 \\
\hline $\begin{array}{l}\text { Socioeconomic groups: Households living } \\
\text { on supplementary welfare allowance }\end{array}$ & 2.6 & 2.8 & 3.2 & 2.8 & 2.9 & 3.9 & 5.9 & 4.2 \\
\hline $\begin{array}{l}\text { Socioeconomic groups: Households of } \\
\text { farmers }\end{array}$ & 2.3 & 2.7 & 2.6 & 2.1 & 3.0 & 4.2 & 5.9 & 4.9 \\
\hline $\begin{array}{l}\text { Socioeconomic groups: Households } \\
\text { having income from other sources }\end{array}$ & 3.2 & 3.7 & 3.7 & 3.2 & 3.8 & 4.8 & 5.9 & 4.9 \\
\hline
\end{tabular}

Commentary: a subjective assessment of the consumption situation associated with food products, clothing and footwear, furniture and durable goods on a five-point scale, where: 1-very good, 5-very bad. In turn, the remaining assessments of satisfying needs will be on a 6-point scale, where: 1—very good, 5-very bad, and 6-not applicable, no need. Source: own work on the basis of [43]. 
Table 7. Comparison satisfying consumer needs in one-person households and multi-person households in Poland.

\begin{tabular}{|c|c|c|c|c|c|c|c|c|}
\hline \multirow[b]{2}{*}{ Types of Households } & \multicolumn{8}{|c|}{ Satisfying Consumer Needs in Terms of: } \\
\hline & Food Products & $\begin{array}{l}\text { Clothing and } \\
\text { Footwear }\end{array}$ & Health Care & $\begin{array}{c}\text { Timely } \\
\text { Payment of } \\
\text { Housing } \\
\text { Charges }\end{array}$ & $\begin{array}{l}\text { Furnishing the } \\
\text { Flat with } \\
\text { Furniture and } \\
\text { Durable } \\
\text { Goods }\end{array}$ & Culture & $\begin{array}{l}\text { Education and } \\
\text { Training }\end{array}$ & $\begin{array}{c}\text { Tourism and } \\
\text { Recreation } \\
\text { Outside the } \\
\text { Place of } \\
\text { Residence }\end{array}$ \\
\hline $\begin{array}{l}\text { One-person households with people } \\
\text { aged } 60 \text { and over }\end{array}$ & 2.1 & 2.6 & 2.6 & 1.8 & 2.8 & 3.8 & 5.9 & 4.2 \\
\hline $\begin{array}{l}\text { One-person households with people } \\
\text { under } 60 \text { years of age }\end{array}$ & 2.0 & 2.3 & 2.5 & 1.8 & 2.6 & 3.0 & 5.2 & 3.3 \\
\hline Households of two and more people & 1.7 & 2.1 & 2.1 & 1.7 & 2.3 & 3.0 & 4.2 & 3.3 \\
\hline
\end{tabular}

Commentary: a subjective assessment of the consumption situation on a five-point scale, where: 1—very good, 5 -very bad. Source: own work on the basis of [43] 


\subsection{Groups of One-Person Households of People 60+}

The aggregate indicator for the standard of living consisted of two components: an aggregate variable providing the objective characteristics of households and an aggregate variable containing a set of subjective characteristics. Objective conditions specific for households positively correlated with subjective assessments expressed by members of these households (Pearson correlation coefficient 0.495) (Figure 2).

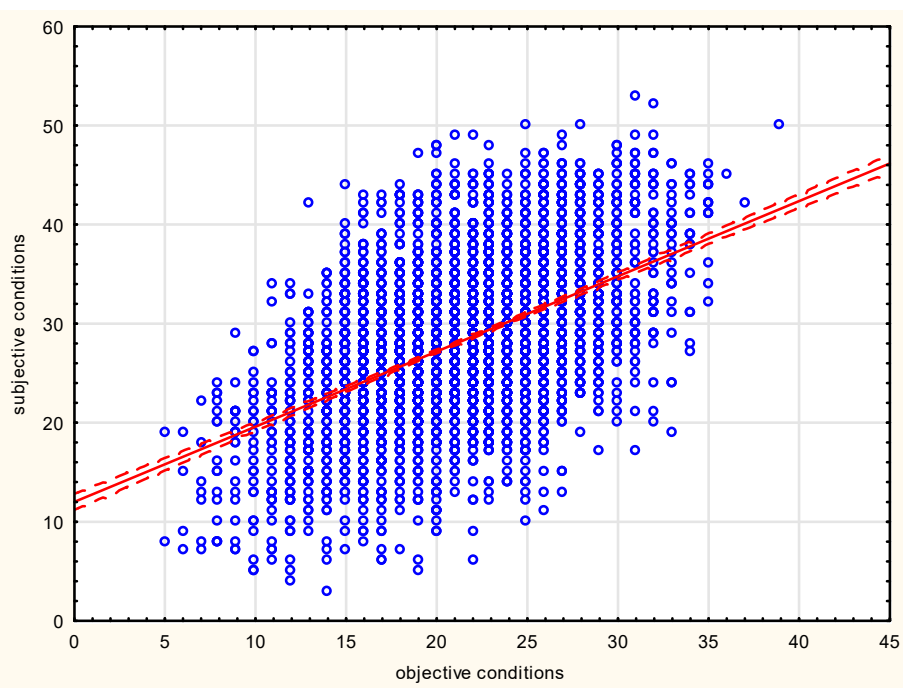

Figure 2. Scatter chart of objective and subjective determinants affecting the standard of living in one-person households of persons aged 60 and over. Source: own work on the basis of [43]

One-person households of the elderly were grouped, using two variables (components of the aggregate indicator). Four groups (clusters) of households were created, with different living standards in terms of both objective and subjective variables. Figure 3 shows that for two groups with the lowest and the highest level of objective factors characterizing the standard of living, subjective ratings are at a similar level. In contrast, for two other groups, the standard of living in the objective approach is far from satisfaction.

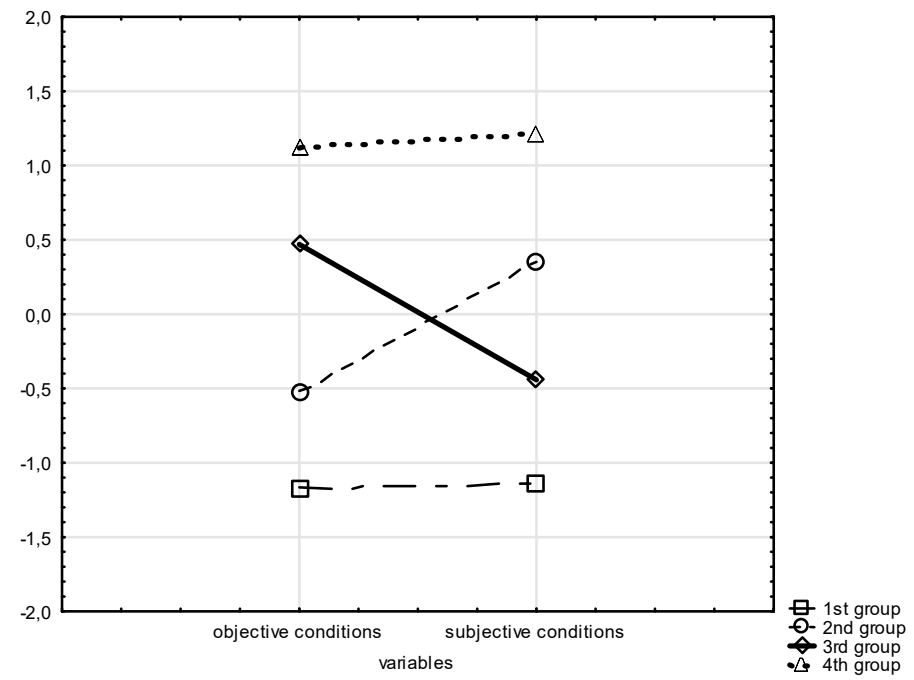

Figure 3. Standardized averages for the groups of one-person households of people aged 60 and over. Source: own work on the basis of [43]. 
The first group included households $(\mathrm{N}=1039)$ with a very low standard of living in which both objective and subjective variables remained at a low level. About half of these households were run by people with the lowest education level. It was reported that in the first group (compared to other groups) there was a relatively high percentage of people living on other social benefits ( $7 \%$ of all households from the first cluster). These were slightly more often than in other groups run by males $(30 \%)$ and by never married $(14 \%)$ or divorced $(14 \%)$ persons. More often than in other groups, these people had held a disability certificate (over 22\%). In the first group, the largest percentage of households was located in the rural areas $(46 \%)$, and the persons lived in statistically significantly smaller apartments $\left(57.4 \mathrm{~m}^{2}\right)$ than in groups third and fourth.

The second group contained one-person households of the elderly $(\mathrm{N}=1341)$, having a relatively low standard of living, while the assessment of the satisfaction of needs was expressed at a relatively high level. The persons running these households were at the lowest education level - secondary or post-secondary (about 35\% for each level). Compared to other groups, the highest percentage of people lived on retirement pensions was 79\%. A relatively high proportion of people making up this group were widowed $(78 \%), 70+$ years old $(57 \%)$. More often than in other clusters, people in this group (23\%) lived in urban areas, of 20-99 thousand inhabitants.

The third group encompassed the elderly forming one-person households ( $\mathrm{N}=1478)$, who had several characteristics (age, place of residence, socio-economic group, marital status) similar to the second group of households, but expressed different opinions on the satisfaction of their household needs. In households from the third group a slightly higher level of objective living conditions was observed compared to households from the second group, however, their subjective assessment was much lower than in the second group. The feature that differentiated these households was the education level: in the third group much more frequently people had secondary and post-secondary education (42\%). Perhaps this fact resulted in a worse assessment of the subjective situation. These people in the past, as it can be assumed, had higher salaries than those from the second group, and after retiring their households' income significantly decreased, which resulted in low satisfaction with their standard of living. The households from the second group more often than others were run by females (over 83\%).

The fourth group comprised one-person households $(\mathrm{N}=1113)$ with the highest standard of living, both in terms of objective characteristics and subjective feeling. The elderly forming this cluster had a relatively high education level: $44 \%$ had secondary and post-secondary education, and $36 \%$ had higher education. A relatively high share of people received their income from work as white-collar employers ( $8 \%$ ). In a slightly lower number of households than in the other groups, the livelihood on disability pensions was declared (14\% compared to $17-19 \%)$. People from the fourth group were slightly younger than in other groups, the share of people aged $60-70$ was $54 \%$. The average age of people was 70.7 years and was statistically significantly different from the age of people from the second and the third groups (72.5 in both groups). Divorced persons represented a relatively high share of households $(16 \%)$. Less often than in other groups, these people had a disability certificate, about $13 \%$. In households from the fourth group, a statistically significantly larger area of housing $\left(68.1 \mathrm{~m}^{2}\right)$ compared to other groups was observed.

\section{Discussion}

Deaton [60] indicates that for development of a policy promoting prosperity and reducing poverty, it is advisable to understand individual consumer choices, especially how consumers divide their expenses into various goods, how much income is spent and how much is saved. The author emphasizes that (despite the declared and implemented help of rich countries for poor countries) the stratification between the poorest and the richest is deepening, and the growing inequality is becoming an increasing demand barrier and threatens the harmonious development of the market economy $[60,61]$. The research highlights large disparities in the standard of living of Poles aged 60 and over, running one-person households. Older people running one-person households are a 
heterogeneous group because of their different socio-economic and demographic characteristics, which affects the different living standards in these households. This statement is also confirmed by other studies review [62-65].

In the conducted analyses, it was noted that people aged 60 and more living on other social benefits and living in the countryside had a particularly low standard of living. The disposable income of these households remained at or below the edge of social minimum (minimum income standard). In other studies [66,67], a particularly difficult life situation of the elderly living in rural areas was also noticed. Older people living in the countryside are often left alone, relying on the help of their neighbors, local authorities and occasional visiting family "from the city" or become a burden and trouble for the family remaining in the village. The changing social and cultural situation as well as social conventions in rural areas has led to the disappearance of traditional forms of community existence. These factors lead the elderly to apathy and deprive their sense of life. Older people, in particular those living in rural areas, are often subject to the phenomenon of social exclusion [68]. The difficult situation of these people has been observed for many years, not only in Poland [69]. Negative social phenomena still exist and even intensify in various actions for sustainable development. Technological progress certainly brought the opportunity to largely fulfill the main idea of actions for the purposes of sustainable development. However, the fact that some areas of social life, e.g., helping the elderly, are still overlooked as one of the goals of societies development, cannot be satisfying [66].

Researchers from other countries [9] show a high increase in a number of one-person households run by the elderly. This is an important that seniors living alone are more likely to be in both in social isolation and poverty. The analysis of the income situation for Czech and Slovak households showed that the group of seniors living alone appears to be the most vulnerable in terms of income insufficiency. If the elderly person stays alone in the household, either by their own decision or because of their partner's death, it means to become "socially" (the danger of social exclusion, or social isolation) and "financially" (the threat of poverty) vulnerable. The abovementioned Authors also pointed, the two examined risks (social and economic) are not the only ones endangering the standard of living among the group of the elderly living in one-person households. This standard is also affected by other threats, for examples related to age and health (either physical or psychological). Moreover, Mareš, Horáková, Rákoczyová [70] indicated that older people living alone are particularly likely to be socially excluded.

The research showed that women had a slightly higher standard of living compared to men, which is also confirmed by the results of research for all one-person households [57]. However, there are opposition results on the received. Pinquart and Sörensen [71] proved that females are reported to feel less satisfied with their lives than men at all ages.

In households of the elderly, health expenditure constitutes an important place in total expenditures. On the other hand, satisfaction with meeting health needs in one-person households of the elderly is not high. Other researchers pointed relationship between good health and successful aging [72], health status is a critical factor in understanding the quality of life, which is closely related to successful aging of older one-person householders [73]. It is also worth noting that the increasing number of older people running one-person households over a dozen or so years [74] will influence the increase in the demand for hospital beds and places in stationary social welfare facilities. The current material base in this respect is insufficient, and it should be noted that while people living with their families can be assumed to have care during convalescence after hospitalization, those forming one-person households require social assistance. Therefore, the challenge for the government policy is to ensure proper standards of the provision of health and care services. This will be particularly important to maintain a decent life among lonely people who may not be able to count on family support.

The percentage of spending on recreation, culture and education services in the households of older people was low. Engagement in cultural and recreational activities enhances personal satisfaction and helps in building social identity. Thus, the elderly require a wide range of recreational activities [75] and cultural activities. Other studies $[57,76]$ indicate that spending time and money for studying and self-studying is not considered by them at all. 
The studies also prove that a "traditional senior" is transformed into a "modern senior" [77]. Pragmatic, thrifty and having very limited requirements, the traditional senior is transformed into a person enjoying consumer lifestyle and standing out, having many different interests, paying attention to the quality of purchased goods. The modern senior as a consumer demonstrates experience, wisdom and vigilance, confidence in making shopping decisions, such a consumer looks for new experiences and challenges and is open to technological novelties [78]. The senior consumer is noticed by various industrial sectors, e.g., clothing and footwear suppliers, producing goods designed for their age. Functional and intelligent products are expected to respond to the voice of the elderly market [79]. The conducted research may constitute premises confirming these statements. People working in white-collar job and running their own business, as well as those with higher education have a relatively good standard of living that allows them to benefit from a wider range of services and goods.

Four groups of one-person households of the elderly were distinguished in the study. In households with the best objective financial and consumption situation, the subjective standard of living was also best assessed. However, in one-person households with the worst financial and consumption situation, people's satisfaction with the achieved standard of living was very low.

Two groups of one-person households were also selected, where the standard of living expressed by objective characteristics was different from subjective assessments. In one of these groups there was a relatively high standard of living in the objective approach, but low satisfaction with the standard of living (subjective approach). In the other group, the situation was reversed. The explanation for this fact can be found in the relative income hypothesis of J. S. Duesenberry.

One of the determinants affecting this fact was the education level. In the case of people with a lower education level, greater satisfaction with the level of satisfied needs as well as both financial status and consumption were observed. On the other hand, in the households run by people with secondary and post-secondary education, although objective characteristics indicated a relatively high standard of living, in subjective terms the achieved standard of living was low. It is worth adding that similar demographic characteristics were observed in both types of households. Other studies [80] pointed to cause-effect relationships between the objective indicators (e.g., income, financial assets) and subjective indicators (e.g., satisfaction with material situation, ability to 'make ends meet'), which is confirmed by the own study regarding the groups with the highest and lowest standard of living. Moreover, a weak correlation is demonstrated between the property and satisfaction with it [81,82], which is confirmed among the groups of households with an average standard of living.

Demographic and social characteristics of household members are responsible for this situation. For example, it was noticed that women having financial debt expressed a much greater burden than men with the same debt [83]. Women were also much less motivated to take financial risk [84]. Studies [85] stated that satisfaction with the financial situation is influenced by age and size of the family, while gender, marital status, occupation and income level do not matter.

\section{Conclusions}

The obtained results should be considered as signal ones for social policy and economic practice helping in taking more decisive and desirable actions. However, it is observed that the share of one-person households run by elderly people in general number of households has increased significantly since the second half of the twentieth century. Due to this phenomenon arises needs to acquire greater insight into their standard of living.

The achieved standard of living was found to be statistically significant for such variables as: socio-economic group, education level, professional activity, household location, gender and marital status. It was noted that in one-person households of people aged 60 and over:

- Receiving income from work as white-collar employers and from own business affected the highest standard of living. On the other hand, professionally active people had a lower standard of living than professionally inactive people;

- $\quad$ Along with the increase in the people education level, their standard of living increased; 
- $\quad$-Standard of living in the rural areas was significantly lower compared to urban areas, while the standard of living in the smallest towns (with population less than 99 thousand) was significantly lower compared to the largest cities (500,000 inhabitants and more);

- Women had a higher standard of living, despite their lower disposable income;

- Never married men and women achieved a significantly lower standard of living than people representing other marital status.

The hierarchy of types of one-person households of the elderly by living standards was based on an aggregate indicator, which was calculated using the ESLI method. At the top and the bottom of the ranking of households by standard of living were the types of households grouped by socio-economic position and education level. The highest standard of living was represented by the households run by white-collar workers, self-employed and highly-educated persons. The lowest standard of living was recorded in households: having income from other sources (without pensions), of farmers, living on supplementary welfare allowance and among persons with lower secondary, primary or less education. Thus, the Hypothesis has been confirmed. Features such as the socioeconomic group and level of education are key factors in the standard of living in one-person households of the elderly.

The observed shift in the population demographic structure is becoming a key problem, it is necessary to diagnose the living conditions of seniors, especially their income and expenses for basic purposes. The group formed by one-person households of elderly is heterogeneous because of their different socio-economic and demographic characteristics, affecting different living standards in these households. It turns out that in some types of households (farmers, people living on social benefits) very low income and consumption expenditure may indicate exclusion of these people from social life. Remedial measures should be taken for these social groups. Issues related to both the level and the quality of life are the basic elements of multi-faceted actions for sustainable development. The effect of actions for the sustainable development should be to ensure a decent level of life for all social groups.

There is also a group of $60+$ people running one-person households whose income and consumption situation is favorable. Public space should be properly managed for these people, as they are interested in making the most of culture and leisure services.

The ageing of the population, resulting from various causes and expressed by the continuous increase in the share of older people in the population, is a huge challenge for the economy and the society. The conducted research provides evidence confirming the low standard of living among numerous one-person households of the elderly. This research may be a basis for building new social policy activities that fit into the postulates of sustainable development in relation to social issues that will reorient the objectives of socio-economic development in the way it would be support for elderly people running a household alone. The actual situation hides a kind of economic "violence" [56]. An important element of the transition to the next stage of sustainable development should be a significant change in the field of society basic values, which should protect the neediest groups in the population.

The higher income and the standard of flat/house equipment, the greater the satisfaction with both the financial situation and meeting the consumer needs. However, this increase in the subjective assessment of living standard is affected by a number of variables, including, for example, the education level.

Funding: The study was financed from the budget of the city of Płock in connection with the Competition of the President of the City of Płock for financing research grants carried out as part of the task "Cooperation with universities".

Acknowledgments: I am grateful to the suggestions and insightful comments of three anonymous reviewers, and the financial assistance by the President of the City of Płock.

Conflicts of Interest: The authors declare no conflict of interest. 


\section{References}

1. Deaton, A. Income, health, and well-being around the world: Evidence from the Gallup world poll. J. Econ. Perspect. 2008, 22, 53-72. [CrossRef] [PubMed]

2. Zhang, X.; Xia, R.; Wang, S.; Xue, W.; Yang, J.; Sun, S.; Zhuang, G. Relative contributions of different lifestyle factors to health-related quality of life in the elderly. Int. J. Environ. Res. Public Health 2018, 15, 256. [CrossRef] [PubMed]

3. Trafiałek, E. Innovative Senior Citizen Policy in the 21st Century: Between Ageism, Social Security, and Active Ageing; Adam Marszalek Publishing House: Torun, Poland, 2016. (In Polish)

4. Boruta, M. Gerontechnology as a tool in the process of satisfying the housing needs of seniors. Prog. Econ. Sci. 2017, 4, 25-36. (In Polish)

5. Salverda, W. Household income inequalities and labour market position in the European Union. CESifo Forum 2018, 19, 35-43.

6. Tarasuk, V.; Fafard St-Germain, A.; Mitchell, A. Geographic and socio-demographic predictors of household food insecurity in Canada, 2011-12. BMC Public Health 2019, 19, 12. [CrossRef] [PubMed]

7. Mohd, S.; Senadjki, A.; Mansor, N. Living arrangements of elderly: Evidence from household income expenditure survey. J. Popul. Ageing 2017, 10, 323-342. [CrossRef]

8. Bongaarts, J.; Zimmer, Z. Living arrangements of older adults in the developing world: An analysis of demographic and health survey household surveys. J. Gerontol. Ser. B Psychol. Sci. Soc. Sci. 2002, 57, S145-S157. [CrossRef]

9. Hazuchová, N.; Stávková, J.; Nagyová, L'.; Poláková, Z.; Vávrová, S. Transformations and perspectives of the living conditions of Czech and Slovak seniors with an emphasis on single-person households. Soc. Econ. 2019, 41, 449-465. [CrossRef]

10. Bialowolski, P.; Weziak-Bialowolska, D. The index of household financial condition, combining subjective and objective indicators: An appraisal of Italian households. Soc. Indic. Res. 2014, 118, 365-385. [CrossRef]

11. Burkhard, D. Allocation of expenditures in elderly households and the cost of widowhood. Swiss J. Econ. Stat. 2017, 153, 371-401. [CrossRef]

12. Hossain, A.; Bailey, G.; Lubulwa, M. Characteristics and Travel Patterns of Older Australians: Impact of Population Ageing on Tourism; Bureau of Tourism Research: Canberra, Australia, 1996.

13. Alcaide Casado, J.C. Donde esta el marketing para mayores? Mark. Ventas 2005, 205, 46-57.

14. Lee, S.H.; Tideswell, C. Understanding attitudes towards leisure travel and the constraints faced by senior Koreans. J. Vacat. Mark. 2005, 11, 249-263. [CrossRef]

15. Garcia Sastre, M.A.; Martorell Cunill, O. Una reflexión sobre el modelo turistico de las Illes Balears. In Proceedings of the XX AEDEM Annual Congress, Madrid, Spain, 6-8 June 2007; pp. 1097-1106.

16. Kowalik, S. (Ed.) Kultura Fizyczna Osób z Niepetnosprawnością; GWP: Gdańsk, Poland, 2009. (In Polish)

17. Cvrlje, D.; Ćorić, T. Macro E Micro Aspects of Standard of Living and Quality of Life in a Small Transition Economy: The case of Croatia; EFZG working paper series; University of Zagreb: Zagreb, Croatia, 2010; Volume 2, pp. 1-12.

18. Chappelow, J. Standard of living. Inestopedia. 29 August 2019. Available online: https://www.investopedia. com/terms/s/standard-of-living.asp (accessed on 25 November 2019).

19. EU. Population: Structure Indicators, Eurostat Database. Available online: https://ec.europa.eu/eurostat/ data/database (accessed on 25 November 2019).

20. Young, M.; Lachapelle, U. Transportation behaviours of the growing Canadian single-person households. Transp. Policy 2017, 57, 41-50. [CrossRef]

21. De Paiva Santos, R.; Gonçalves, A.M.; Pereira, B.C.; Caliari, T.M.; Araujo, W.C.T.; Pereira, D.S.; Weeks, L.E. Elderly people living alone. Fisioter. Bras. 2019, 20, 448-459. [CrossRef]

22. Reher, D.; Requena, M. Elderly women living alone in Spain: The importance of having children. Eur. J. Ageing 2017, 14, 311-322. [CrossRef]

23. Bennett, J.; Dixon, M. Single Person Households and Social Policy: Looking Forwards; Joseph Rowntree Foundation: York, UK, 2006.

24. United Nations. Living Arrangements of Older Persons Around the World; United Nations: New York, NY, USA, 2005.

25. Ogburn, W.F.; Nimkoff, M.F. Technology and the Changing Family; Houghton Mifflin: Boston, MA, USA, 1955. 
26. Hugo, G.J. Population Mobility in West Java; Gajah Mada University Press: Jakarta, Indonesia, 1978.

27. Hugo, G.J. Rural-urban migration, economic development and social change: Some important issues. In Workshop on Urbanization and Urban Poor on July; 1991; pp. 27-29.

28. Moreno, A.; Vicente-Virseda, J.A. Family situation, social protection, and well-being of older adults from an European comparative perspective. Res. Ageing Soc. Policy 2016, 4, 96-127. [CrossRef]

29. De Witt, L.; Ploeg, J. Caring for older people living alone with dementia: Healthcare professionals' experiences. Dementia 2016, 15, 221-238. [CrossRef]

30. Chen, Y.; While, A.E. Older people living alone in Shanghai: A questionnaire survey of their life experience. Health Soc. Care Community 2019, 27, 260-269. [CrossRef]

31. Abell, J.; Steptoe, A. Living alone and mortality: More complicated than it seems. Eur. Heart J. Qual. Care Clin. Outcomes 2019, 5, 187-188. Available online: https://discovery.ucl.ac.uk/id/eprint/10073187/1/Abell\% 20\&\%20Steptoe\%20Living\%20alone\%20editorial.pdf (accessed on 21 November 2019). [CrossRef]

32. Bieńkuńska, A.; Sobestjański, K. (Eds.) Poverty in Poland in 2015 and 2016; Central Statistical Office: Warsaw, Poland, 2017. (In Polish)

33. CSO. Households Budget Surveys in 2006, .. . , 2018; CSO: Warsaw, Poland, 2007-2019.

34. CSO. Yearly Price Indices of Consumer Goods and Services from 1950; CSO: Warsaw, Poland, 2019. Available online: https://stat.gov.pl/en/topics/prices-trade/price-indices/price-indices-of-consumer-goodsand-services/yearly-price-indices-of-consumer-goods-and-services-from-1950/ (accessed on 21 November 2019).

35. Davis, A.; Hirsch, D.; Padley, M. The minimum income standard as a benchmark of a 'participatory social minimum'. J. Poverty Soc. Justice 2018, 26, 19-34. [CrossRef]

36. ZUS. Structure of the Amount of Benefits Paid by ZUS after Valorisation in March 2019; ZUS: Warsaw, Poland, 2019. (In Polish)

37. IPiSS. Information on the Level of Social Minimum in 2018 (Based on Average Annual Data); IPiSS: Warsaw, Poland, 2019. (In Polish)

38. KRUS. Indexation of Agricultural Pensions from 1 March 2019. Available online: https: //www.krus.gov.pl/zadania-krus/swiadczenia/swiadczenia-z-ubezpieczenia-emerytalno-rentowego/ waloryzacja-emerytur-i-rent-rolniczych (accessed on 25 November 2019). (In Polish)

39. Balbi, S.; Villa, F. Beyond Ecosystem Services: A Food Security Perspective; Technical Report 2016. No. 2016-04. Available online: https://www.bc3research.org/index.php?option=com_wpapers\&task=downpubli\&iddoc= 87 \&repec $=1$ \&Itemid $=279$ (accessed on 25 November 2019).

40. Yeh, W.C. Living arrangements and lifestyle satisfaction among the elderly in Chinese immigrant families: A preliminary study. Chang Gung Med J. 2003, 26, 729-736. [PubMed]

41. Barr, N. Gender and Family: Conceptual Overview; The World Bank: Washington, DC, USA, 2019.

42. Zalega, T. Consumer behaviour of young Polish singles-selected issues. Marketing i Rynek 2019, 4, 3-14. [CrossRef]

43. Individual dane $\mathrm{z}$ badania budżetów gospodarstw domowych. In Główny Urząd Statystyczny, Warszawa 2018 (Database in Polish)/Individual Data from the Household Budget Survey; Central Statistical Office: Warsaw, Poland, 2018.

44. Filmer, D.; Scott, K. Assessing Asset Indices; The World Bank: Washington, DC, USA, 2008.

45. Breheny, M.; Stephens, C.; Henricksen, A.; Stevenson, B.; Carter, K.; Alpass, F. Measuring living standards of older people using Sen's capability approach: Development and validation of the LSCAPE-24 (living standards capabilities for elders) and LSCAPE-6. Ageing Soc. 2016, 36, 307-332. [CrossRef]

46. Ngo, D.K.L. A theory-based living standards index for measuring poverty in developing countries. J. Dev. Econ. 2018, 130, 190-202. [CrossRef]

47. Jensen, J.; Spittal, M.; Crichton, S.; Sathiyandra, S.; Krishnan, V. Direct Measurement of Living Standards: The New Zealand ELSI Scale; Ministry of Social Development: Wellington, New Zealand, 2002.

48. Melchers, R.E.; Beck, A.T. Structural Reliability Analysis and Prediction; John Wiley \& Sons: West Sussex, UK, 2018.

49. Bonett, D.G.; Wright, T.A. Cronbach's alpha reliability: Interval estimation, hypothesis testing, and sample size planning. J. Organ. Behav. 2015, 36, 3-15. [CrossRef]

50. Cho, E.; Kim, S. Cronbach's coefficient alpha: Well known but poorly understood. Organ. Res. Methods 2015, 18, 207-230. [CrossRef] 
51. Taber, K.S. The use of Cronbach's alpha when developing and reporting research instruments in science education. Res. Sci. Educ. 2018, 48, 1273-1296. [CrossRef]

52. Abdi, H.; Lynne W., J. Newman-Keuls test and Tukey test. In Neil Salkind (Ed.) Encyclopedia of Research Design; Sage: Thousand Oaks, CA, USA, 2010; pp. 1-11.

53. Hennig, C.; Meila, M.; Murtagh, F.; Rocci, R. (Eds.) Handbook of Cluster Analysis; CRC Press: Boca Raton, FL, USA, 2015.

54. Sokołowski, A. Empirical Significance Tests in Taxonomy; University of Economics in Krakow: Krakow, Poland, 1992; Volume 108. (In Polish)

55. Jung, Y.; Park, H.; Du, D.Z.; Drake, B.L. A decision criterion for the optimal number of clusters in hierarchical clustering. J. Glob. Optim. 2003, 25, 91-111. [CrossRef]

56. Kalinowski, S. Living Standards of Rural Population with Uncertain Income; PWN Scientific Publishing House: Warsaw, Poland, 2015. (In Polish)

57. Piekut, M. One-Person Households in Poland_Functioning Conditions, Trends; CeDeWu: Warsaw, Poland, 2019. (In Polish)

58. Bowman, C.G. Living apart together as a 'family form' among persons of retirement age: The appropriate family law response. Fam. Law Q. 2019, 52, 1-25.

59. Emery, J.C.; Fleisch, V.; McIntyre, L. How a Guaranteed Annual Income could Put Food Banks out of Business; SPP Research Paper; The School of Public Policy: Calgary, Canada, 2013.

60. Deaton, A. Przez ciemność w stronę jaśniejszej przyszłości. In Gospodarka za 100 Lat. Najważniejsi Ekonomiści Przewiduja Przyszłość, Red. I; Palacios-Huerta, Kurhaus Publishing: Warsaw, Poland, 2014. (In Polish)

61. Galvin, R.; Sunikka-Blank, M. Economic inequality and household energy consumption in high-income countries: A challenge for social science based energy research. Ecol. Econ. 2018, 153, 78-88. [CrossRef]

62. Dommaraju, P. One-person households in India. Demogr. Res. 2015, 32, 1239-1266. [CrossRef]

63. Haustein, S. Mobility behavior of the elderly: An attitude-based segmentation approach for a heterogeneous target group. Transportation 2012, 39, 1079-1103. [CrossRef]

64. Fernández-Carro, C. Movers or stayers? Heterogeneity of older adults' residential profiles across Continental Europe. Eur. Spat. Res. Policy 2012, 19. [CrossRef]

65. Zhao, L.; Burge, G. Housing wealth, property taxes, and labor supply among the elderly. J. Labor Econ. 2017, 35, 227-263. [CrossRef]

66. Słaby, T. Sustainable development-Forgotten areas of research. Consum. Dev. 2016, 4, 54-66. (In Polish)

67. Şahin, E.; Topkaya, N.; Gençoğlu, C.; Ersanlı, E. Prevalence and correlates of hopelessness among Turkish elderly people living with family or in nursing homes. Societies 2018, 8, 39. [CrossRef]

68. Dabrowska, A.; Gutkowska, K.; Janoś-Kresło, M.; Słaby, T. Social Exclusion-The Quality and Dignity of Life of People Aged 60+ of the Native Inhabitants of Villages in Poland; Publishing House of Warsaw School of Economics: Warsaw, Poland, 2016. (In Polish)

69. Schwenk, F.N. Income and consumer expenditures of rural elders. Fam. Econ. Rev. 1994, 7, $20-27$.

70. Mareš, P.; Horáková, M.; Rákoczyová, M. Sociální Exkluze na Lokální Úrovni; VÚPSV: Prague, Czech Republic, 2008; (Monograph in Czech).

71. Pinquart, M.; Sörensen, S. Gender differences in self-concept and psychological well-being in old age: A meta-analysis. J. Gerontol. Ser. B Psychol. Sci. Soc. Sci. 2001, 56, P195-P213. [CrossRef]

72. Rowe, J.W.; Kahn, R.L. Successful aging. Gerontologist 1997, 37, 433-440. [CrossRef]

73. Ahn, M.; Lee, S.-J. Housing satisfaction of older (55+) single-person householders in US rural communities. J. Appl. Gerontol. 2016, 35, 878-911. [CrossRef]

74. Gołata, E.; Kuropka, I. Demographic changes and their consequences for selected areas of social policy in large cities in Poland. Econ. Stud. 2015, 223, 162-173. (In Polish)

75. Blace, N.P. Functional ability, participation in activities and life satisfaction of the older people. Asian Soc. Sci. 2012, 8, 75-87. [CrossRef]

76. Knapková, M.; Kaščáková, A. Use of time in single-member households in Slovakia. Ekonomie a Management 2018, 21, 40-57. [CrossRef]

77. Jurek, Ł. Polityka społeczna wobec ludzi starych w USA-Uwarunkowania rozwoju i perspektywy zmian. Nauk. Spoleczne 2012, 5, 23-39. (In Polish)

78. Bombol, M.; Słaby, T. Consumer 55+ Is a Challenge for the Market; Warsaw School of Economics-Publishing House: Warsaw, Poland, 2011. (In Polish) 
79. Palamutcu, S.; Goren, I. Functional textile preferences of elderly people. Mediterr. J. Soc. Sci. 2015, 6, 279. [CrossRef]

80. Wilhelm, M.S.; Varcoe, K.; Fridrich, A.H. Financial satisfaction and assessment of financial progress: Importance of money attitudes. Financ. Couns. Plan. 1993, 4, 181-198.

81. Hira, T.K.; Mugenda, O.M. Predictors of financial satisfaction: Differences between retirees and non-retirees. J. Financ. Couns. Plan. 1998, 9, 75.

82. Li-Ping Tang, T.; Li-Na Tang, T.; Yazmeen Homaifar, B. Income, the love of money, pay comparison, and pay satisfaction: Race and gender as moderators. J. Manag. Psychol. 2006, 21, 476-491. [CrossRef]

83. Keese, M. Who feels constrained by high debt burdens? Subjective vs. objective measures of household debt. J. Econ. Psychol. 2012, 33, 125-141. [CrossRef]

84. Dickason-Koekemoer, Z.; Ferreira, S. Risk tolerance: The influence of gender and life satisfaction. J. Econ. Behav. Stud. 2019, 11, 66-72. [CrossRef]

85. Sadiq, M.N.; Khan, R.A.A.; Bashir, M.K. Individuals demographic differences and financial satisfaction: Evidence from Pakistan. Bus. Econ. J. 2018, 9, 3. [CrossRef]

(C) 2020 by the author. Licensee MDPI, Basel, Switzerland. This article is an open access article distributed under the terms and conditions of the Creative Commons Attribution (CC BY) license (http://creativecommons.org/licenses/by/4.0/). 